\title{
ANALISIS PENYELESAIAN KONTRAK ASURANSI MELALUI LEMBAGA OTORITAS JASA KEUANGAN
}

\author{
INSURANCE CONTRACT SETTLEMENT ANALYSIS THROUGH FINANCIAL SERVICES \\ AUTHORITY INSTITUTIONS
}

B. Rini Heryanti, Dewi Tuti Muryati, Efi Yulistyowati

\begin{abstract}
ABSTRAK
Perkembangan penyelesaian sengketa asuransi melalui ADR, banyak diminati oleh para pihak yang bersengketa.karena dirasa lebih realistis, mudah, murah, dan cepat tanpa harus mengorbankan faktor kepastian. Penyelesaian sengketa kontrak asuransi melalui jalur non litigasi/ADR dapat diselesaikan melalui BMAI yang telah didirikan pada tahun 2006, di tahun 2011 pemerintah juga telah mendirikan OJK yang mempunyai tugas untuk melakukan pengawasan disektor jasa keuangan bank dan non bank, yang didalamnya salah satu tugasnya adalah melakukan penyelesaian sengketa asuransi.

Perumusan masalah yang diteliti adalah, bagaimanakah kewenangan Otoritas Jasa Keuangan (OJK) dalam penyelesaian sengketa hukum kontrak asuransi?, bagaimanakah kedudukan BMAI kedepanya, setelah didirikannya OJK ?

Metode yang digunakan dalam penelitian ini, metode pendekatan yuridis normatif, dengan spesifikasi deskriptif analitis, sedangkan teknik pengumpulan data menggunakan data primer dan data sekunder.

Hasil penelitian pengaduan dan penyelesaian sengketa asuransi oleh OJK secara umum diatur dalam Pasal 29 Undang-Undang No.21 tahun 2011.Memperhatikan Pasal 29 tersebut mengamanatkan OJK untuk menyiapkan perangkat, menyusun mekanisme, dan memfasilitasi penyelesaian pengaduan konsumen yang dirugikan oleh pelaku di lembaga jasa keuangan, maka OJK mengeluarkan Peraturan OJK No.1/POJK. 07/2013 tentang Perlindungan Konsumen Sektor Jasa Keuangan dan Surat Edaran OJK No.2/SEOJK. 07/2014 tentang Pelayanan dan Penyelesaian Pengaduan Konsumen Pada Pelaku Usaha Jasa Keuangan, sedangkan kedudukan BMAI setelah adanya OJK berada dibawah OJK.
\end{abstract}

Kata kunci : Sengketa asuransi, BMAI,OJK

\section{ABSTRACT}

The development of the insurance dispute resolution through ADR, much in demand by the parties to bersengketa.felt to be more realistic, easier, cheaper, and faster without sacrificing the certainty factor. Dispute settlement insurance contract through the non litigation / ADR can be resolved through BMAI which had been established in 2006, in 2011 the government has also set up the FSA, which has the task to pass surveillance sector financial services of banks and non-banks, which includes one of his tasks is to insurance dispute resolution.

The formulation of the problem under study is, how does the authority of the Financial Services Authority (FSA) in insurance contract law dispute resolution?, How BMAI position, after the establishment of the FSA?

The method used in this research, normative juridical approach, the analytical descriptive specification, while the data collection techniques using primary data and secondary.

The research result of complaints and the settlement of disputes by the FSA insurance is generally provided for in article 29 of Law 21 years 2011. Article 29 mandates the FSA to set up the equipment, develop mechanisms and facilitate the resolution of consumer complaints were harmed by the offender in the financial services institution, the FSA issued a FSA Regulation 1 / POJK.07 / 2013 on Consumer Protection and Financial Services Sector FSA Circular No.2 / SEOJK.07 / 2014 on the Ministry and the Consumer Complaint Settlement In Financial Services business communities, while the position of BMAI, the FSA under the FSA.

Keywords: insurance disputes, BMAI, FSA. 


\section{a. Pendahuluan.}

Perusahaan asuransi mempunyai peran yang strategis di masyarakat, hal ini menjadikan perusahaan asuransi semakin dirasakan sebagai kebutuhan akan jasa proteksi baik bagi individu maupun dunia usaha di Indonesia, dengan semakin banyaknya permintaan akan jasa proteksi ini, pertumbuhan perusahaan asuransi di Indonesia semakin meningkat, sampai dengan tahun 2013 jumlah perusahaan asuransi mencapai 140 (seratus empat puluh), dan jumlah perusahaan penunjang asuransi mencapai 260 (dua ratus enam puluh) perusahaan (BPS).

Pesatnya perkembangan usaha asuransi ini sering tidak diimbangi dengan kesiapan sumber daya manusianya (pelaku bisnis, agen), dalam mengelola bisnis asuransi ini, sehingga di dalam masyarakat muncul berbagai macam konflik atau sengketa asuransi yang paling banyak timbul di praktik sengketa selalu berasal pada kontrak/ perjanjian asuransi.

Jika terjadi sengketa asuransi antara penanggung dan tertanggung maka para pihak yang bersengketa dapat menyelesaikan sengketa yang dialaminya lewat jalur pengadilan/litigasi mauun di luar pengadilan/non litigasi. Penyelesaian sengketa yang diselesaikan melalui jalur pengadilan/litigasi, diatur dalam Pasal 1266 Kitab Undang-Undang Hukum Perdata, dan penyelesaian sengketa diluar pengadilan dapat dilakukan melalui Alternative Dispute Resolution (ADR).

Perkembangan penyelesaian sengketa asuransi melalui ADR, banyak diminati oleh para pihak yang bersengketa hal ini disebabkan perkembangan masyarakat dalam bidang penyelesaian sengketa sudah semakin berkembang ke arah yang lebih realistis, mudah, murah, dan cepat tanpa harus mengorbankan faktor kepastian hukum.

Penyelesaian sengketa kontrak asuransi melalui jalur non litigasi/ADR dapat diselesaikan melalui Badan Mediasi Asuransi Indonesia (BMAI) yang khusus dibentuk oleh Federasi Asosiasi Perasuransian Indonesia (FAPI) untuk menangani sengketa-sengketa asuransi, badan ini didirikan sejak tahun 2006 hingga sekarang.

Pada tahun 2011 pemerintah dengan UndangUndang Republik Indonesia Nomor 21 Tahun 2011 telah membentuk Otoritas Jasa Keuangan (OJK), terkait dengan tugas OJK di dalam Bab IV Pasal 28 sampai dengan Pasal 31 Undang-Undang No 21 Tahun 2011 tentang Otoritas Jasa Keuangan dinyatakan bahwa OJK berwenang melakukan tindakan pencegahan kerugian konsumen, melakukan pelayanan pengaduan konsumen dan berwenang melakukan pembelaan hukum. Untuk melaksanakan ketentuan pasal-pasal tersebut OJK mengeluarkan Peraturan Otoritas Jasa Keuangan
No.1/POJK.7/2013 tentang Perlindungan Konsumen Sektor Jasa Keuangan, dan ditindak lanjuti dengan ditebitkannya Surat Edaran Otoritas Jasa Keuangan No.2/SEOJK.07/2014 tentang Pelayanan Dan Pengaduan Konsumen. Surat Edaran ini dibuat sebagai bentuk perlindungan terhadap konsumen sesuai amanat UU No.21 Tahun 2011 tentang Otoritas Jasa Keuangan. Dengan dibentuknya lembaga Otoritas Jasa Keuangan maka lembaga ini mempunyai kewenangan juga untuk menyelesaikan sengketa kontrak asuransi seperti halnya pembentukan BMAI yang telah didirikan terlebih dahulu.

\section{Perumusan Masalah}

Berdasarkan gambaran secara umum di atas, maka perlu kiranya diadakan penelitian mengenai Analisis Penyelesaian Sengketa Kontrak Asuransi Melalui OJK dengan rumusan permasalahan sebagai berikut :

1. Bagaimanakah kewenangan Otoritas Jasa Keuangan (OJK) dalam penyelesaian sengketa hukum kontrak asuransi ?

2. Bagaimanakah kedudukan BMAI kedepanya, setelah didirikannya OJK ?

\section{b. Kajian Pustaka}

\section{Pengertian Lembaga Asuransi}

Perusahaan asuransi merupakan suatu perusahaan yang secara profesional siap menerima transfer risiko dan memberi perlindungan serta jaminan terhadap kerugian dari obyek yang diasuransikan sebagaimana disebutkan dalam Pasal 246 KUHD.

Demikian pula yang disebutkan dalam Pasal 1 ayat (1) Undang-Undang Nomor 40 Tahun 2014 tentang Perasuransian :

"Asuransi adalah perjanjian antara dua pihak, yaitu perusahaan asuransi dan pemegang polis, yang menjadi dasar bagi penerimaan premi oleh perusahaan asuransi sebagai imbalan untuk :

a. Memberikan penggantian kepada tertanggung atau pemegang polis karena kerugian, kerusakan, biaya yang timbul, kehilangan keuntungan, atau tangung jawab hukum kepada pihak ke tiga yang mungkin diderita tertanggung atau pemegang polis karena terjadinya suatu peristiwa yang tidak pasti; atau

b. Memberikan pembayaran yang didasarkan pada meninggalnya tertangung dengan manfaat yang besarnya telah ditetapkan dan/atau didasarkan pada hasil pengelolaan dana. 
Undang-Undang No.21 Tahun 2011 tentang Otoritas Jasa Keuangan, asuransi dimasukkan kedalam lembaga jasa keuangan, seperti yang tercantum dalam Pasal 1 ayat4; Lembaga Jasa Keuangan adalah lembaga yang melaksanakan kegiatan di sektor Perbankan, Pasar Modal, Perasuransian, Dana Pensiun, dan Lembaga Jasa Keuangan lainnya.Selain itu, dalam Peraturan OJK No.1/POJK.07/ 2013 tentang Perlindungan Konsumen Sektor Jasa Keuangan Pasal 1, Perusahaan Asuransi ini termasuk dalam Pelaku Jasa Keuangan, disamping Bank Umum, Bank Perkreditan Rakyat, Perusahaan Efek, Penasihat Investasi, Bank Kustodium, Dana Pensiun, Perusanaan Reasuransi, Lembaga Pembiayan, Perusahaan Gadai dan Perusahaan Penjaminan

\section{Perjanjian asuransi}

Perjanjian asuransi merupakan suatu perjanjian yang memiliki ciri-ciri khusus jika dibandingkan dengan perjanjian lainnya. ${ }^{1}$

Perjanjian asuransi tidak termasuk dalam perjanjian yang hanya diatur dalam KUH Perdata saja melainkan diatur pula dalam KUH Dagang. Pasal 246 KUHD merupakan landasan/dasar adanya perjanjian asuransi dan terdapat pasal-pasal lain yang mendukung adanya perjanjian tersebut seperti yang diatur dalam Pasal 250, 251, 253, 247, 258, 266.

Dari apa yang tercantum dalam isi pasal tersebut, oleh Emmy Pangaribuan dijabarkan bahwa perjanjian asuransi atau pertanggungan mempunyai sifat-sifat sebagai berikut: $^{2}$

a. Perjanjian asuransi atau pertanggungan pada asasnya adalah suatu perjanjian penggantian kerugian (shcadeverzekering atau indemniteits contract).

b. Perjanjian asuransi atau pertanggungan adalah perjanjian timbal balik.

c. Kerugian yang diderita adalah sebagai akibat dari peristiwa yang tidak tertentu atas mana diadakan pertanggungan.

Sebagai azas dasar terjadinya dan sahnya serta pelaksanaan dari perjanjian asuransi, Herman Darmawi menyatakan ada 4 (empat) hal yang harus terpenuhi yakni :3

1 Sri Rejeki Hartono, Hukum Asuransi dan Perusahaan Asuransi, (Jakarta: Sinar Grafika, 1997), halaman 92.

2 Emmy Pangaribuan Simanjuntak, Hukum Pertanggungan,( Universitas Gajahmada, 1990), halaman 16.

3 Herman Damawi, Manajemen Asuransi, (Jakarta: Bumi Aksara,2004), halaman 27.
a. adanya azas itikad baik yang lebih luas dan diperkuat dengan syarat-syarat khusus tertentu,
b. adanya kepentingan,
c. pemberian ganti rugi berdasarkan azas keseimbangan,
d. adanya taksiran/taksasi

\section{Pengertian Sengketa Konsumen.}

Menurut Az.Nasution, sengketa konsumen dapat diartikan sebagai setiap perselisihan antar konsumen dan penyedia barang dan/atau jasa pelaku usaha dalam hubungan hukum antara satu sama lain mengenai produk tersebut. ${ }^{4}$

Sengketa konsumen terjadi karena adanya ketidak puasan konsumen terhadap suatu produk atau kerugian yang dialami konsumen karena penggunaan atau pemakaian barang atau jasa. Dengan demikian sengketa konsumen disebabkan oleh adanya kerugian yang disebabkan cacat tubuh (personal injury), cacat fisik (injury to the produk it self), dan kerugian ekonomi (pure economic loss).

\section{Penyelesaian Sengketa Asuransi}

Cara penyelesaian sengketa dapat dilakukan lewat pengadilan dan di luar pengadilan, penyelesaian sengeketa memakai metode non litigasi banyak disukai oleh pelaku bisnis,karena dapat lebih menekankan pada hal membina hubungan bisnis, metode penyelesaian yang tepat adalah negosiasi, mediasi, atau konsiliasi. Metode ini dikenal dengan Alternatif Penyelesaian Sengketa/ APS, ada juga yang menyebutnya sebagai Alternatif Dispute Resolution/ADR, atau PSLP.

\section{Lembaga Alternatif Penyelesaian Sengketa}

a) Badan Mediasi Asuransi Indonesia (BMAI)

BMAI didirikan dengan tujuan untuk memberikan pelayanan yang profesional dan transparan yang berbasis pada kepuasan dan perlindungan serta penegakkan hak-hak tertanggung atau pemegang polis melalui proses mediasi dan ajudikasi, serta mengupayakan penyelesaian sengketa klaim secara lebih cepat, adil, murah dan informal. Lembaga ini hanya memproses sengketa yang terjadi antara pemegang polis dan perusahaan asuransi.

Az. Nasution, Op Cit, halam 178. 
b) Otoritas Jasa Keuangan (OJK). Tujuan pendirian OJK berlandaskan Undang-Undang No.21 Tahun 2011 tentang Otoritas Jasa Keuangan yakni :

1) Mendorong kegiatan sektor jasa keuangan agar terselenggara secara teratur, adil, transparan dan akuntabel,

2) Mewujudkan sistem keuangan yang tumbuh secara berkelanjutan dan stabil,

3) Melindungi kepentingan konsumen dan masyarakat.

\section{c. Metode Penelitian}

\section{Metode Pendekatan}

Metode pendekatan yang dipakai dalam penelitian ini adalah metode yuridis normatif. ${ }^{5}$

\section{Spesifikasi Penelitian}

Spesifikasi pada penelitian ini adalah deskriptif analitis karena bertujuan memberikan gambaran secara menyeluruh, mendalam tentang suatu keadaan atau gejala yang diteliti. ${ }^{6}$

\section{Teknik Pengumpulan Data}

Sesuai dengan fokus utama penelitian yaitu yuridis normatif, maka data-data yang hendak dikumpulkan adalah data sekunder dari hukum positif, yang meliputi bahan-bahan hukum, baik bahan hukum primer, bahan hukum sekunder, dan bahan hukum non hukum.

\section{Analisis Data}

Berdasarkan data yang dikumpulkan dalam penelitian ini kemudian di analisis secara kualitatif.

\section{d. Hasil dan Pembahasan}

1. Kewenangan Otoritas Jasa Keuangan (OJK) dalam penyelesaian sengketa hukum kontrak asuransi.

Setelah melalui masa krisis yang melanda Indonesia pada tahun 1998, perkembangan dunia bisnis asuransi mulai mengeliat menampakkan perkembangan yang baik, hal ini dapat dilihat dari pertumbuhan perusahaan asuransi yang ada baik asuransi umum, asuransi jiwa, dari data yang masuk pada BPS sampai dengan tahun 2013 jumlah perusahaan asuransi mencapai 140 (seratus empat puluh),

5 Ronny Hanitijo Soemitro, Metodologi Penelitian Hukum dan Jurimetri, (Ghalia Indonesia, Jakarta, 1990), halaman 22.

${ }^{6}$ Soerjono Soekanto, Pengantar Penelitian Hukum, Cet.III, UI Press, Jakarta, 1986, halaman. 10 dan jumlah perusahaan penunjang asuransi mencapai 260 (dua ratus enam puluh) perusahaan. Berdasarkan data Asosiasi Asuransi Jiwa Indonesia (AAJI) hingga Juni 2013, perolehan premi di asuransi jiwa tumbuh 14,48\% menjadi Rp.57,59 triliun. Pertumbuhan premi baru tumbuh $70 \%$, sedangkan pertumbuhan premi lanjutan mencapai $31,25 \%$. Peningkatan premi ini didorong oleh meningkatnya kesadaran masyarakat untuk berasuransi.

Hingga tahun 2014 industri asuransi mampu mencatat pertumbuhan premi, untuk asuransi jiwa pertumbuhannya di kisaran $15 \%$ hingga 20\% dan asuransi umum di kisaran $8 \%$ hingga $13 \%$ serta pertumbuhan premi asuransi jiwa masih di dorong pertumbuhan asuransi unit link (produk perusahaan asuransi jiwa yang mengawinkan fungsi proteksi dan investasi,dalam rencana keuangan, investasi dan proteksi adalah dua hal wajib dimiliki) ${ }^{7}$. Pertumbuhan industri asuransi dengan peningkatan premi yang diperoleh sampai saat ini, tidak luput dari peran para agen asuransi. Agen asuransi masih menjadi ujung tombak dan tulang punggung perolehan premi pada perusahaan asuransi.

Pesatnya pertumbuhan industri asuransi di Indonesia, sering tidak diikuti dengan pengelolaan perusahaan asuransi dengan baik, baik manajemenya maupun sumber daya manusianya dalam hal ini agen asuransi. Sehingga banyak menimbulkan sengketa asuransi. Banyaknya sengketa asuransi yang terjadi baik pengaduan sengketa yang masuk melalui Badan Mediasi Asuransi Indonesia (BMAI) maupun melalui Otoritas Jasa Keuangan, seperti yang ada dalam data rekapitulasi sengketa yang diterima BMAI sejak berdirinya sampai September 2014 adalah :

Tabel 1

\begin{tabular}{|l|c|c|c|c|}
\hline KETERANGAN & $\begin{array}{c}\text { As. } \\
\text { Umum }\end{array}$ & $\begin{array}{c}\text { As } \\
\text { Jiwa }\end{array}$ & $\begin{array}{c}\text { As. } \\
\text { Sosial }\end{array}$ & Total \\
\hline $\begin{array}{l}\text { September 2006 - } \\
2012\end{array}$ & 213 & 217 & 4 & 434 \\
\hline Tahun 2013 & 14 & 27 & - & 41 \\
\hline Tahun 2014 & 24 & 17 & - & 41 \\
\hline $\begin{array}{l}\text { Total sengketa } \\
\text { sampai tahun } \\
2014\end{array}$ & 251 & 261 & 4 & 516 \\
\hline
\end{tabular}

Rekapitulasi Sengketa yang diterima BMAI dari bulan September 2006 sampai dengan 2014.

\footnotetext{
${ }^{7}$ Infobank Outlook 2014, halaman 73

${ }^{8}$ B.Rini Heryanti,2010. Hukum Perusahaan Asuransi, Semarang University Press.halaman 80.
} 
Sedangkan pengaduan sengketa asuransi yang masuk pada OJK sampai tahun 2014 jumlah laporan yang diterima sebanyak 413, sebanyak 260 diantaranya berupa permintaan informasi, 50 penyampaian informasi, dan sisanya 31 adalah aduan dari luar yang ditangani Direktorat Asuransi, dan 72 laporan diantaranya berupa pengaduan yang terkait dengan permasalahan Industri Keuangan Nonbank (IKNB), khususnya pengaduan asuransi. ${ }^{9}$

Sengketa asuransi mayoritas yang terjadi disebabkan tidak dibayarnya klaim asuransi yang paling banyak diadukan bermuara pada kontrak. Tertanggung/nasabah asuransi/pemegang polis apabila mengalami sengketa kontrak asuransi maka pihak yang dirugikan dapat menyelesaikan sengketanya lewat jalur pengadilan dan di luar pengadilan atau litigasi dan non litigasi. Penyelesaian sengketa melalui pengadilan. Jalur non litigasi dapat diselesaikan melalui badanbadan yang telah terbentuk yakni BMAI dan OJK.

Terbentuknya lembaga OJK pada tahun 2011, membawa angin baru dalam pengaduan sengketa asuransi bagi para pihak yang mengalami kerugian, konsumen dapat menyampaikan pengaduan yang berindikasi sengketa antara Pelaku Usaha Jasa Keuangan, pelanggaran peraturan di sektor jasa keuangan kepada OJK. Pengaduan dan penyelesaian sengketa asuransi oleh OJK secara umum diatur dalam Pasal 29 Undang-Undang No.21 tahun 2011.

Memperhatikan Pasal 29 tersebut yang mengamanatkan OJK untuk menyiapkan perangkat, menyusun mekanisme, dan memfasilitasi penyelesaian pengaduan konsumen yang dirugikan oleh pelaku di lembaga jasa keuangan, maka OJK mengeluarkan Peraturan OJK No.1/POJK.07/2013 tentang Perlindungan Konsumen Sektor Jasa Keuangan dan Surat Edaran OJK No.2/SEOJK.07/ 2014 tentang Pelayanan dan Penyelesaian Pengaduan Konsumen Pada Pelaku Usaha Jasa Keuangan yang diterbitkan tanggal 14 Februari 2014.

Pengaduan sengketa asuransi oleh konsumen/ tertanggung yang dapat difasilitasi oleh OJK yakni;

a. Konsumen/tertanggung yang mengalami kerugian financial di bidang asuransi umum paling banyak sebesar Rp.750.000.000,- (tujuh ratus lima puluh juta rupiah).

b. Pelaku Jasa Keuangan telah melakukan upaya penyelesaian pengaduan namun konsumen tidak dapat menerima penyelesaian tersebut atau telah melewati batas waktu sebagaimana

\footnotetext{
${ }^{9}$ http://www.republika.co.id/berita/ekonomi/keuan gan/20/3/2014
}

ditetapkan dalam Peraturan Otoritas Jasa Keuangan,

c. Pengaduan yang diajukan bukan merupakan sengketa sedang dalam proses atau pernah diputus oleh lembaga arbitrase atau peradilan, atau lembaga meditasi lainnya,

d. Pengaduan yang diajukan bersifat keperdataan,

e. Pengaduan yang diajukan belum pernah difasilitasi oleh OJK,

f. Pengajuan penyelesaian pengaduan tidak melebihi 60 (enam puluh) hari kerja sejak tanggal surat hasil penyelesaian pengaduan yang disampaikan PelakuUsaha Jasa Keuangan Kepada Konsumen.

OJK telah menetapkan kebijakan bahwa penyelesaian di sektor jasa keuangan dilakukan dengan 2 (dua) tahapan. Untuk penyelesaian di tahap pertama adalah tugas dari lembaga jasa keuangan terlebih dahulu untuk menyelesaikan pengaduan yang disampaikan oleh konsumen. Di tahap ke dua dilakukan apabila tidak tercapai kesepakatan dalam penyelesaian pengaduan tersebut, maka konsumen dan lembaga jasa keuangan dapat menyelesaikan sengketanya melalui pengadilan atau di luar pengadilan.

Adapun mekanisme penyelesaian sengketa asuransi yang dilakukan oleh OJK yakni, adanya pengaduan dari konsumen atau tertanggung yang dapat disampaikan kepada Otoritas Jasa Keuangan baik secara fisik melalui media yang telah disediakan maupun secara elektronik melalui Sistem Pelayanan Konsumen Terintegrasi Sektor Jasa Keuangan.

Apabila syarat para pihak yang melakukan pengaduan telah memenuhi syarat yang telah ditentukan oleh OJK, maka OJK akan mempertemukan konsumen dengan pelaku usaha jasa keuangan terlebih dahulu untuk mengkaji ulang permasalahan secara mendasar dalam rangka memperoleh kesepakatan penyelesaian. Untuk melaksanakan fungsinya sebagai lembaga penyelesaian sengketa asuransi, maka OJK menunjuk fasilitator.

Otoritas Jasa Keuangan memulai proses fasilitasi setelah Konsumen dan Pelaku usaha Jasa Keuangan sepakat untuk difasilisitasi oleh Otoritas Jasa Keuangan yang dituangkan dalam perjanjian fasilitasi yang memuat :

a) kesepakatan untuk memilih penyelesaian pengaduan yang difasilitasi oleh Otoritas Jasa Keuangan; dan

b) persetujuan untuk patuh dan tunduk pada aturan fasilitasi yang ditetapkan oleh Otoritas Jasa Keuanganan.

Jangka waktu pelaksanaan proses fasilitasi paling lama 30 (tiga puluh) hari kerja sejak sejak 
Konsumen dan Pelaku Usaha Jasa Keuangan menandatangani perjanjian fasilitasi sampai dengan ditandatanganinya Akta Kesepakatan. Jangka waktu ini dapat diperpanjang sampai 30 (tiga puluh) hari kerja berikutnya berdasarkan Akta Kesepakatan Konsumen dan Pelaku Usaha Jasa Keuangan.

Kesepakatan antara Konsumen dengan Pelaku Usaha Jasa Keuangan yang dihasilkan dari proses fasilitasi dituangkan dalam Akta Kesepakatan yang ditandatangani oleh Konsumen dan Pelaku Usaha Jasa Keuangan, apabila terjadi ketidaksepakatan antara Konsumen dengan Pelaku Usaha Jasa Keuangan, maka ketidaksepakatan tersebut dituangkan dalam berita acara hasil fasilitasi Otoritas Jasa Keuangan yang ditandatangani oleh Konsumen dengan Pelaku Usaha Jasa Keuangan.

Agar Akta Kesepakatan tersebut dapat dipatuhi oleh kedua belah pihak, maka Pelaku Jasa Keuangan (perusahaan asuransi) diwajibkan melakukan pengendalian internal yakni melakukan pengawasan atas pelaksanaan tanggung jawab direksi atau pengurus terhadap ketaatan pelaksanaan Akta Kesepakatan tersebut, tercakup didalamnya pelaksanaan prinsip-prinsip perlindungan konsumen, sistem pelaporan dan monitoring terhadap tindak lanjut pengaduan konsumen. Di pihak OJK melakukan pengawasan baik langsung maupun tidak langsung kepada Pelaku Jasa Keuangan terhadap penerapan ketentuan perlindungan konsumen.

Penyelesaian pengaduan sengketa asuransi antara Konsumen/Tertanggung dengan Pelaku Usaha Jasa Keuangan dalam hal ini lembaga asuransi sebagaimana telah diuraikan di atas, landasan yuridisnya yaitu Pasal 40,41,42, 43, 44,45, dan 46 yang diatur dalam Peraturan Otoritas Jasa Keuangan No.1/POJK.07/2013 tentang Perlindungan Konsumen Sektor Jasa Keuangan.

Kewenangan OJK dalam penyelesaian sengketa kontrak asuransi ini sejalan dengan Undang-Undang Otoritas Jasa Keuangan No.21 tahun 2011, Bab IV Pasal 30 mengenai perlindungan konsumen dan masyarakat.

\section{Kedudukan BMAI setelah terbentuknya OJK}

Berdirinya BMAI pada tanggal 12 Mei 2006 ini berdasarkan Surat Keputusan bersama empat menteri yakni:

1) Menteri Koordinator bidang Perekonomian dengan surat keputusan Nomor. KEP.45/ M.Ekon/07/2006

2) Gubernur Bank Indonesia dengan surat keputusan Nomor 8/KEP 6.BI/2006

3) Menteri keuangan surat keputusan Nomor : 357/KMK/012/2006
4) Menteri Badan Usaha Milik Negara dengan surat Keputusan No. KEP.7/MBU/2006

Sejak berdirinya BMAI hingga kini sudah banyak pengaduan yang masuk dan sudah tertangani dengan baik. Namun tidak semua sengketa asuransi dapat diajukan ke BMAI. Badan ini hanya menangani sengketa klaim asuransi maksimal Rp.750 juta (tujuh ratus lima puluh rupiah), untuk asuransi jiwa dan asuransi jaminan sosial, sedangkan sengketa yang tidak bisa diselesaikan lewat BMAI diantaranya sengketa yang menyangkut penetapan premi, kebijakan yang berhubungan dengan suku bunga dan biayabiaya standar aktuaria dan tindak kriminal. Disisi lain dalam penyelesaian sengketa klaim asuransi terdapat lembaga lain yang berwenang untuk melakukan penyelesaian sengketa asuransi, yakni OJK.

Konsumen dapat mengajukan pengaduan kepada BMAI atau OJK, sebab ke dua lembaga ini sama-sama mensyaratkan bahwa kasus yang disengketakan sudah pernah diselesaikan di masing-masing perusahaan asuransi/pelaku usaha namun tidak terjadi kesepakatan di kedua belah pihak. Melihat dalam putusan/sanksi yang diberikan kepada perusahaan asuransi/pelaku usaha, maka OJK lebih menjanjikan adanya kepastian hukum yakni dapat memberikan peringatan tertulis sampai dengan pencabutan ijin usaha asuransi. Melihat kenyataan terebut, maka bisa saja tertanggung/pemegang polis/konsumen lebih senang untuk memilih penyelesaian sengketanya lewat OJK, karena disamping sanksi yang diberikan lebih berat, pelaku jasa keuanganpun diharuskan untuk melakukan pengendalian internal atas pelaksanaan akta kesepakatan yang menjadi kehendak para pihak. Jadi konsumen asuransi merasa lebih terlindungi jika menyelesaikan sengketanya melalui OJK.

Menilik dari tahun pendiriannya, BMAI lebih dahulu dibentuk daripada OJK, namun kalau dilihat dari kewenangan yang dimiliki OJK lebih mempunyai kewenangan yang luas daripada BMAI.

Dengan diterbitkannya peraturan Otoritas Jasa Keuangan (POJK) Nomor 1/POJK.07/2014, tanggal 16 Januari 2014 tentang lembaga Alternatif Penyelesaian Sengketa disektor jasa keuangan oleh Otoritas Jasa Keuangan R.I, BMAI harus mengadakan penyesuaian dan perbaikan peraturan pada proses penyelesaian sengketa asuransi agar BMAI dapat diterima sebagai LAPS yang diakui oleh OJK.

Penyesuaian dan perbaikan tersebut telah dilakukan dengan menerbitkan surat Keputusan BMAI No. 001/SK.BMAI/11.2014 tanggal 1 November 2014 tentang Peraturan dan Prosedur Ajudikasi BMAI dan SK No. 002/SK-BMAI/ 
11.2014 tentang peraturan dan prosedur Mediasi Badan Mediasi dan Arbitrase Asuransi Indonesia (BMAI), dengan diterbitkannya kedua Surat Keputusan BMAI tersebut diatas maka Keputusan BMAI No. 001/SK-BMAI/04.2010 tentang Proses Penanganan Sengketa Melalui Mediasi dan /atau Ajudikasi dan Petunjuk pelaksanaan Proses atau Prosedur Penanganan sengketa nyatakan tidak berlaku lagi.

Mengenai kedudukan BMAI, setelah adanya pendirian OJK oleh pemerintah banyak menimbulkan polemik di dunia industri asuransi dan pengamat ekonomi, akankah BMAI diatas atau dibawah OJK? Sampai saat ini masih menjadi perdebatan yang panjang.

Namun berdasarkan data serta peraturan yang ada sebaiknya BMAI tetap dipertahankan dan lebih dioptimalkan mengingat BMAI didirikan berdasarkan koordinasi asosiasi dai perusahaan-perusahaan asuransi di seluruh Indonesia. Hal ini berarti peran BMAI sangat dibutuhkan oleh perusahaan asuransi ketika perusahaan asuransi menemui ketidak sepakatan dalam menyelesaikan gugatan tanggung jawab polis (Liability) dan nilai ganti kerugian (Quantum of claim).

Sejak tahun 2003 dengan surat Keputusan Menteri Keuangan, KMK 422/KMK06/2003 mewajibkan semua polis asuransi harus mencantumkan klausula tata cara penyelesaian sengketa asuransi. Seperti yang telah dilaksanakan bahwa penyelesaian sengketa asuransi dapat diselesaikan lewat /melalui pengadilan dan diluar pengadilan. Melalui jalur di luar pengadilan berarti melalui LAPS. Salah satu LAPS di bidang perasuransian inilah BMAI bahkan dalam perkembangannya sekarang ini dalam polis dicantumkan pemberitahuan penting (Important Notice) dalam hal penyelesaian sengketa asuransi yang menyosialisasikan mengenai

Mengingat tujuan, fungsi, dan wewenang OJK yang telah tercantum dalam Pasal 4 sampai dengan Pasal 9 Undang-undang No. 21 tahun 2011 tentang Otoritas Jasa Keuangan, dan pembentukan LAPS diseluruh sektor jasa keuangan yang dilakukan OJK serta mencermati peraturan-peraturan yang telah dikeluarkan oleh OJK ,maka kedudukan BMAI berada dibawah OJK.

\section{e. Simpulan}

1. Berdasarkan Pasal 29 Undang-Undang No.21 Tahun 2011 tentang Otoritas Jasa Keuangan, dan Peraturan Otoritas Jasa Keuangan No.1/POJK.07/2013 tentang Perlindungan Konsumen Sektor Jasa Keuangan serta Surat Edaran Otoritas Jasa Keuangan No.2/ SEOJK.07/2014 tentang Pelayanan dan Penyelesaian
Pengaduan Konsumen. Kewenangan OJK dalam melakukan penyelesaian sengketa konsumen dilakukan dengan mekanisme sebagai berikut :

a. Pengaduan konsumen kepada OJK dapat disampaikan secara fisik melalui media yang telah disediakan maupun secara elekronik melalui Sistem Pelayanan Konsumen Terintegrasi Sektor Jasa Keuangan,

b. Apabila para pihak yang melakukan pengaduan telah memenuhi syarat sesuai ketentuan yang disyaratkan OJK, maka OJK akan mempertemukan pelaku usaha jasa keuangan dengan konsumen untuk mengkaji ulang permasalahan secara mendasar, guna memperoleh kesepakatan penyelesaian,

c. OJK menunjuk fasilitator,

d. OJk membuat perjanjian fasilitasi,

e. Kesepakatan antara konsumen dengan pelaku usaha jasa keuangan yang dihasilkan dituangkan dalam Akta kesepakatan,

f. Apabila terjadi ketidaksepakatan antara konsumen dengan pelaku jasa keuangan, maka ketidaksepakatan tersebut dituangkan dalam dalam berita acara hasil fasilitas Otoritas Jasa Keuangan yang ditandatanganin oleh konsumen dengan Pelaku Usaha Jasa Keuangan,

g. OJK melakukan pengawasan atas pelaksanaan Akta Kesepakatan tersebut.

2. Kedudukan Badan Mediasi Asuransi Indonesia setelah berdirinya OJK.

Peran otoritas lebih kepada mendorong dan memastikan bahwa industri jasa keuangan mempunyai mekanisme penyelesaian sengketa yang memadai.

OJK mengharuskan pembentukan lembaga Penyelesaian Sengketa Konsumen di masing-masing sektor paling lambat 31 Desember 2015, berkaitan dengan perannya untuk melakukan pengawasan dan pembinaan LAPS yang telah terbentuk dan LAPS yang dapat melakukan penyelesai sengketa di sektor masingmasing jasa keuangan adalah LPAS yang sudah terdaftar di OJK.

Mengingat tujuan, fungsi, dan wewenang OJK yang telah tercantum dalam Pasal 4 sampai dengan Pasal 9 Undang-undang No. 21 tahun 2011 tentang Otoritas Jasa Keuangan, dan pembentukan LAPS 
diseluruh sektor jasa keuangan yang dilakukan OJK serta mencermati peraturan-peraturan yang telah dikeluarkan oleh OJK, maka kedudukan BMAI berada dibawah OJK.

\section{f. Saran}

1. Perlu ditingkatkan adanya sosialisasi yang dilakukan oleh BMAI maupun OJK dalam rangka pelayanan penyelesaian sengketa konsumen.

2. Perlu adanya koordinasi yang dilakukan oleh OJK dengan lembaga-lembaga perlindungan konsumen baik di sektor jasa maupun disektor barang yang sudah ada sebelumnya, seperti BPSK, Kementerian Perdagangan dalam hal ini Direktorat Jendral Standarisasi dan Perlindungan Konsumen, BPKN, untuk menghindari friksi tumpang tindih terkait dengan pengaturan dan pembinaan serta pengawasan mekanisme penyelesaian sengketa

\section{DAFTAR PUSTAKA}

\section{Buku-buku}

Abdul Hakim Barkatullah, 2010, Hak - hak Konsumen, Bandung Nusa Media

Adrian Sutedi, 2014, Aspek Hukum Otoritas Jasa Keuangan, Raih Asa Sukses.

Az Nasution, 2001, Hukum Perlindungan Konsumen Sebagai Pengantar, Jakarta, Diadit Media.

Adul Halim Barkatullah, 2010, Hak-Hak Konumen, Bandung, Nusa Media.

Emmy Pangaribuan Simanjuntak, 1990, Hukum Pertanggungan, Universitas Gajahmada.

Hadawi Nawawi, Instrumen Penelitian Bidang Sosial, Yogyakarta,Gajah Mada University Press.
Herman Darnawi, 2004, Manajemen Risiko, Jakarta : Bumi Aksara.

Ronny Hanitijo Soemitro, 1990, Metodologi Penelitian Hukum dan Jurimetri, Jakarta, Ghalia

Shidarta, 2000, HukumPerlindungan Konsumen,Jakarta : Grasindo

Sri Rejeki Hartono, 1997, Hukum Asuransi dan Perusahaan Asuransi, Jakarta: Sinar Grafika,

Soerjono Soekanto, 1986, Pengantar Penelitian Hukum, Jakarta, UI Press.

Otoritas Jasa Keuangan, 2014, Road Map Penyelesaian Sengketa di sektor Jasa Keuangan.

Zaidatul Amina, 2012, Kapan Pembentukan Otoritas Jasa Keuangan di Indonesia Dari Pengalaman Di Negara Lain, Surabaya.

\section{Peraturan Perundang-undangan}

Kitab Undang-undang Hukum Perdata

Kitab Undang-undang Hukum Dagang

Undang-Undang Nomor 21 Tahun 2011 tentang Otoritas Jasa Keuangan,

Undang-undang Nomor 40Tahun 2014 tentang Perasuransian

Peraturan Otoritas Jasa Keuangan Nomor: 1/POJK.07/2013

Surat Edaran Otoritas Jasa Keuangan Nomor : 2/SEOJK.07/2011

\section{Intenet}

http://www.republika.co.id/berita/ekonomi/keuang an/13/02/2014

www.pikiran rakyat.com/node/233972 